\title{
African Research of Michał Kobusiewicz: Calendar and Bibliography
}

\section{Przemysław Bobrowski ${ }^{a}$}

Abbreviations used in the text:

CPE Combined Prehistoric Expedition;

PCMA Center of Mediterranean Archaeology, Warsaw University;

DOP-PU Dakhleh Oasis Project - Petroglyph Unit;

IAE PAS Institute of Archaeology and Ethnology Polish Academy of Sciences.

Table I. Calendar of African study visits of Michał Kobusiewicz.

\begin{tabular}{lllll}
$\begin{array}{l}\text { Year } \\
(\mathbf{m o n t h})\end{array}$ & Country & Site & $\begin{array}{l}\text { Chronology } \\
\text { /Period }\end{array}$ & $\begin{array}{l}\text { Mission } \\
\text { (project manager) }\end{array}$ \\
\hline 1967 & Sudan & $\begin{array}{l}\text { Debba, } \\
\text { Khashm El Girba } \\
\text { Area }\end{array}$ & $\begin{array}{l}\text { Palaeolithic, } \\
\text { Neolithic }\end{array}$ & $\begin{array}{l}\text { CPE } \\
\text { Joel L. Shiner }\end{array}$ \\
\hline $\begin{array}{l}1969 \\
\text { Feb., Mar. }\end{array}$ & Egypt & $\begin{array}{l}\text { Fayum } \\
\text { Area }\end{array}$ & Stone Age & $\begin{array}{l}\text { CPE } \\
\text { Northern Fayum Project } \\
\text { Fred Wendorf }\end{array}$ \\
\hline $\begin{array}{l}1970 \\
\text { Jul., Aug. }\end{array}$ & Lebanon & Nahr Ibrahim Cave & Palaeolithic & $\begin{array}{l}\text { Columbia University } \\
\text { Ralph Solecki }\end{array}$ \\
\hline $\begin{array}{l}1973 \\
\text { Jan. }\end{array}$ & Egypt & $\begin{array}{l}\text { Bir Sahara, Bir Tarfawi } \\
\text { (Western Desert) }\end{array}$ & Palaeolithic & $\begin{array}{l}\text { CPE } \\
\text { Fred Wendorf and Romuald Schild }\end{array}$ \\
\hline $\begin{array}{l}1974 \\
\text { Feb., Mar. }\end{array}$ & Egypt & $\begin{array}{l}\text { Bir Sahara, Bir Tarfawi } \\
\text { (Western Desert) }\end{array}$ & Palaeolithic & $\begin{array}{l}\text { CPE } \\
\text { Fred Wendorf and Romuald Schild }\end{array}$ \\
\hline $\begin{array}{l}1975 \\
\text { Feb., Mar. }\end{array}$ & Egypt & $\begin{array}{l}\text { Gebel Nabta } \\
\text { (Western Desert) }\end{array}$ & Neolithic & $\begin{array}{l}\text { CPE } \\
\text { Fred Wendorf and Romuald Schild }\end{array}$ \\
\hline & & & &
\end{tabular}

a Institute of Archaeology and Ethnology, Polish Academy of Sciences, Rubież Street 46, 6I-6I2 Poznan, Poland; e-mail: przemyslawbobrowski@iaepan.poznan.pl; ORCID: 0000-0002-7537-1856 
I8 $\mid$ Przemystaw Bobrowski

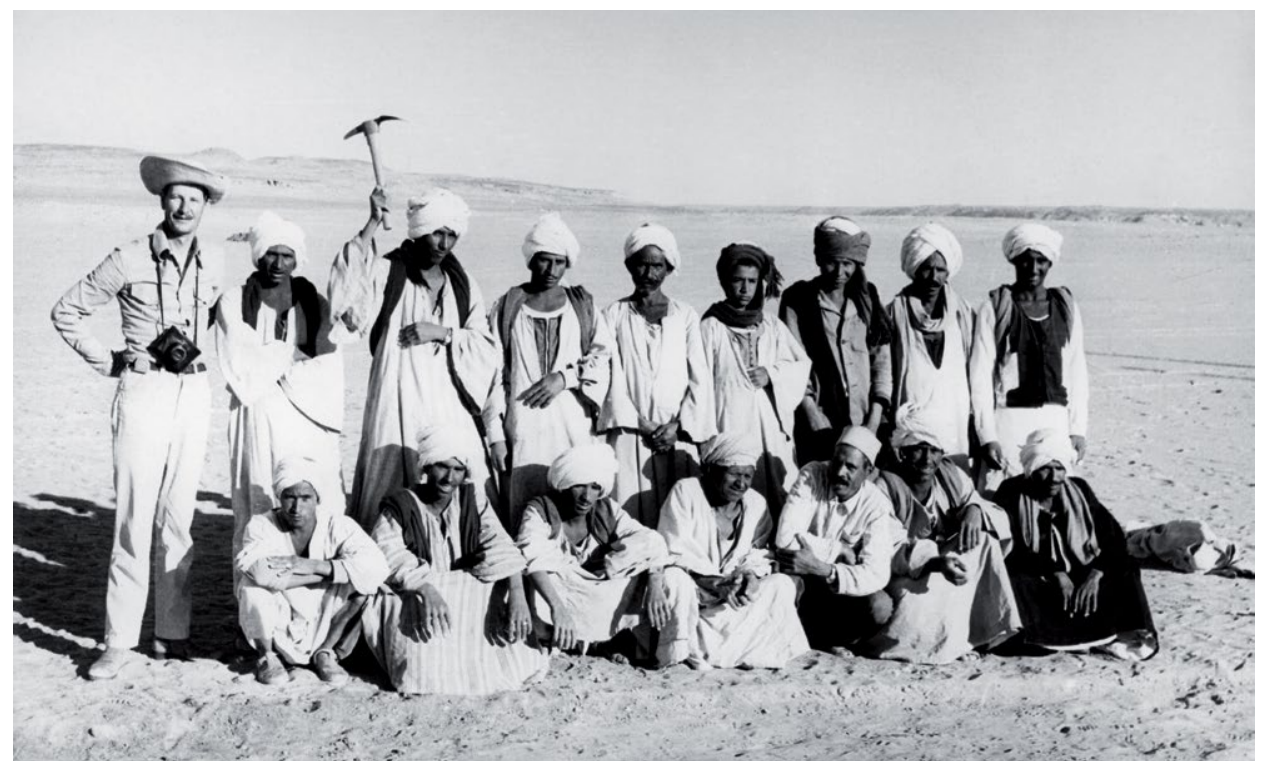

Fig. I. Gebel Nabta, Egypt, Western Desert (1976). Michał Kobusiewicz with workers, Bedouins from the Maarif clan. Photo: M. Kobusiewicz, private collection.

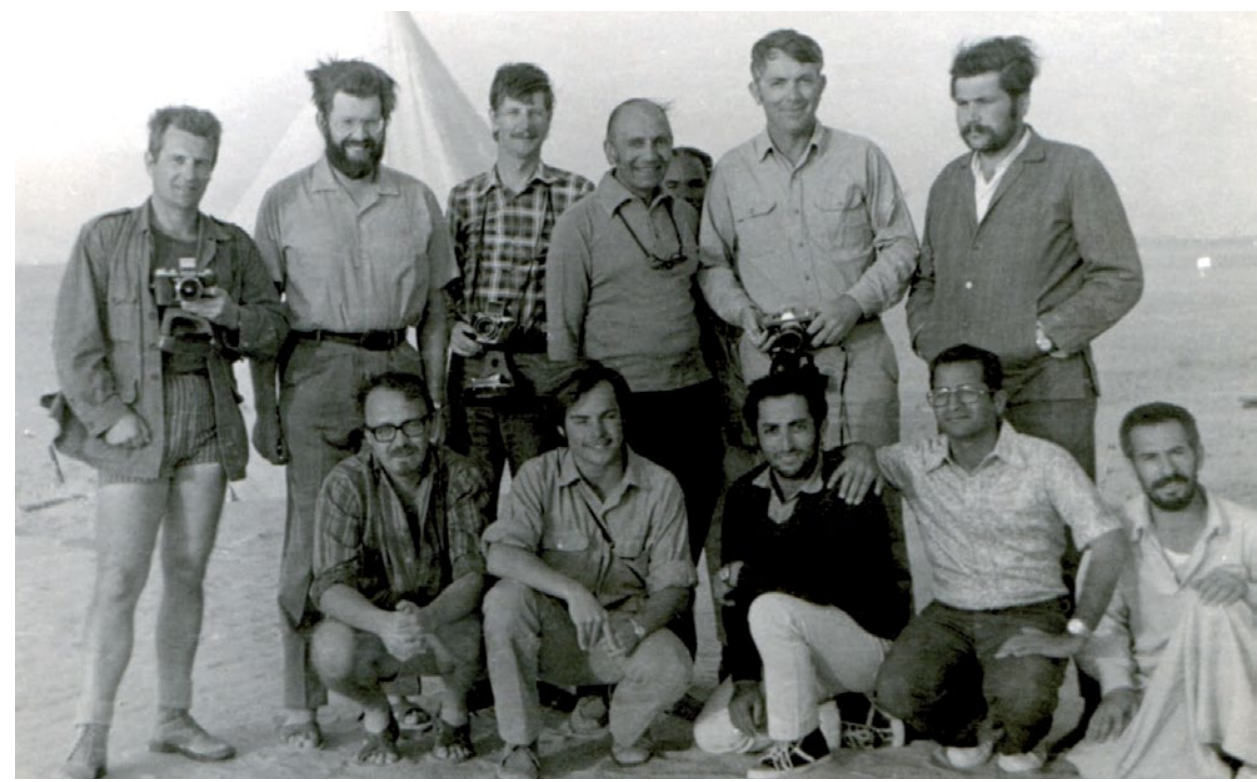

Fig. 2. Bir Sahara, Egypt, Western Desert (1974). Standing, from the left: Romuald Schild, Peter Jeschofnig, Michał Kobusiewicz, Rushdi Said (Director, Geological Survey of Egypt), Fred Wendorf, Mohammad el Hinnawi (Geological Survey of Egypt).

Kneeling, from left: Achilles Gautier, Michael Wendorf and staff of the Geological Survey of Egypt. Photo: Vance Haynes (private collection of M. Kobusiewicz). 


\begin{tabular}{|c|c|c|c|c|}
\hline $\begin{array}{l}\text { Year } \\
\text { (month) }\end{array}$ & Country & Site & $\begin{array}{l}\text { Chronology } \\
\text { / Period }\end{array}$ & $\begin{array}{l}\text { Mission } \\
\text { (project manager) }\end{array}$ \\
\hline $\begin{array}{l}1977 \\
\text { Jan., Feb. }\end{array}$ & Egypt & $\begin{array}{l}\text { Gebel Nabta } \\
\text { (Western Desert) }\end{array}$ & Neolithic & $\begin{array}{l}\text { CPE } \\
\text { Fred Wendorf and Romuald Schild }\end{array}$ \\
\hline 1978 & Egypt & $\begin{array}{l}\text { Wadi Kubbaniya } \\
\text { (Nile Valley) }\end{array}$ & Palaeolithic & $\begin{array}{l}\mathrm{CPE} \\
\text { Fred Wendorf and Romuald Schild }\end{array}$ \\
\hline $\begin{array}{l}1979 \\
\text { Jan.-Mar. }\end{array}$ & Egypt & $\begin{array}{l}\text { Bir Kiseiba } \\
\text { (Western Desert) }\end{array}$ & Neolithic & $\begin{array}{l}\mathrm{CPE} \\
\text { Fred Wendorf and Romuald Schild }\end{array}$ \\
\hline $\begin{array}{l}1980 \\
\text { Jan.-Mar. }\end{array}$ & Egypt & $\begin{array}{l}\text { Bir Kiseiba } \\
\text { (Western Desert) }\end{array}$ & Neolithic & $\begin{array}{l}\mathrm{CPE} \\
\text { Fred Wendorf and Romuald Schild }\end{array}$ \\
\hline $\begin{array}{l}1982 \\
\text { Feb., Mar. }\end{array}$ & Egypt & $\begin{array}{l}\text { Wadi Kubbaniya } \\
\text { (Nile Valley) }\end{array}$ & Palaeolithic & $\begin{array}{l}\mathrm{CPE} \\
\text { Fred Wendorf and Romuald Schild }\end{array}$ \\
\hline $\begin{array}{l}1982 \\
\text { Dec. }\end{array}$ & Sudan & Kadero & Neolithic & $\begin{array}{l}\text { PCMA } \\
\text { Lech Krzyżaniak }\end{array}$ \\
\hline $1982 / 1983$ & Sudan & $\begin{array}{l}\text { Survey along Blue Nile } \\
\text { (to Roseires); } \\
\text { Sennar, Jebel Moya }\end{array}$ & Prehistory & $\begin{array}{l}\text { PCMA } \\
\text { Lech Krzyżaniak }\end{array}$ \\
\hline $\begin{array}{l}1983 \\
\text { Jan., Feb. }\end{array}$ & Egypt & $\begin{array}{l}\text { Wadi Kubbaniya } \\
\text { (Nile Valley) }\end{array}$ & Palaeolithic & $\begin{array}{l}\mathrm{CPE} \\
\text { Fred Wendorf and Romuald Schild }\end{array}$ \\
\hline $\begin{array}{l}1986 \\
\text { Jul.-Sep. }\end{array}$ & Egypt & $\begin{array}{l}\text { Kom El-Hisn } \\
\text { (West Delta) }\end{array}$ & Old Kingdom & $\begin{array}{l}\text { University of Washington / } \\
\text { American Research Center } \\
\text { Robert Wenke }\end{array}$ \\
\hline $\begin{array}{l}1987 \\
\text { Jan. }\end{array}$ & Sudan & Kadero & Neolithic & $\begin{array}{l}\text { PCMA } \\
\text { Lech Krzyżaniak }\end{array}$ \\
\hline $\begin{array}{l}1988 \\
\text { Apr.-Jun. }\end{array}$ & Egypt & $\begin{array}{l}\text { Kom El-Hisn } \\
\text { (West Delta) }\end{array}$ & Old Kingdom & $\begin{array}{l}\text { University of Washington/ } \\
\text { American Research Center } \\
\text { Robert Wenke }\end{array}$ \\
\hline $\begin{array}{l}1988 \\
\text { Sep.- Nov. }\end{array}$ & Egypt & $\begin{array}{l}\text { Minshat Abu Omar } \\
\text { (East Delta) }\end{array}$ & Predynastic & $\begin{array}{l}\text { National Museum of the Egyptian } \\
\text { Art, Munich } \\
\text { Dietrich Wieldung }\end{array}$ \\
\hline $\begin{array}{l}1989 \\
\text { Feb., Mar. }\end{array}$ & Sudan & Kadero & Neolithic & $\begin{array}{l}\text { PCMA } \\
\text { Lech Krzyżaniak }\end{array}$ \\
\hline $\begin{array}{l}1991 \\
\text { Nov., Dec. }\end{array}$ & Sudan & Kadero & Neolithic & $\begin{array}{l}\text { PCMA } \\
\text { Lech Krzyżaniak }\end{array}$ \\
\hline $\begin{array}{l}1993 \\
\text { Nov. }\end{array}$ & Sudan & Kadero & Neolithic & $\begin{array}{l}\text { PCMA } \\
\text { Lech Krzyżaniak }\end{array}$ \\
\hline
\end{tabular}


20 Przemystaw Bobrowski

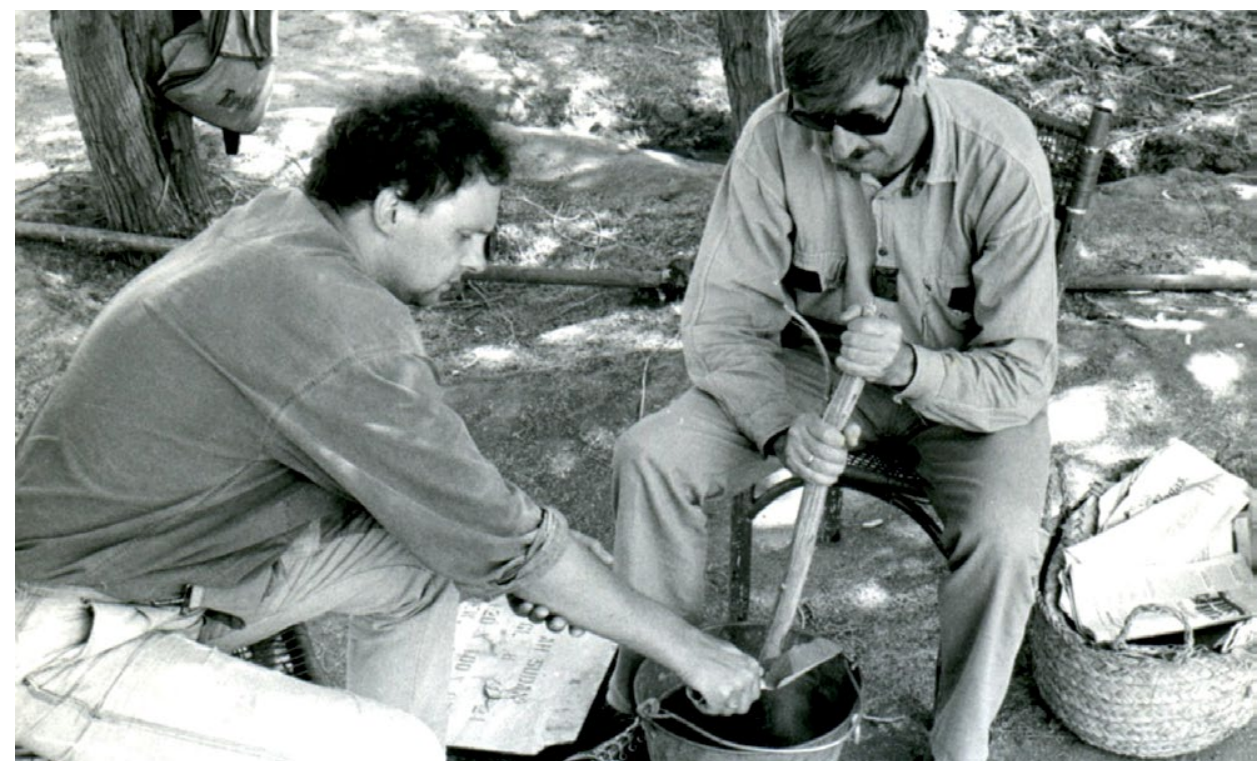

Fig. 3. Kadero, Sudan (1987). Michał Kobusiewicz with Jacek Kabaciński during an experiment. Photo: L. Krzyżaniak.

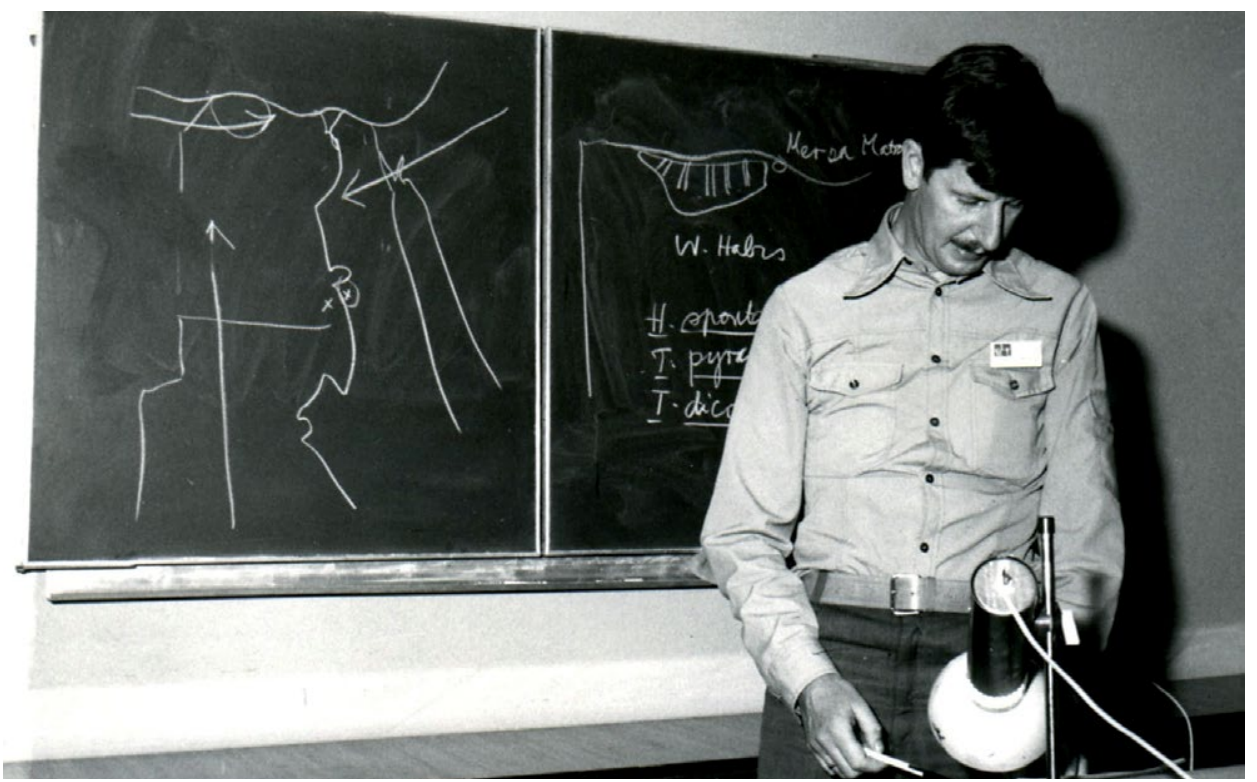

Fig. 4. Dymaczewo near Poznan, Poland (1988). Michał Kobusiewicz presenting a paper at a conference. Photo: M. Kobusiewicz, private collection. 


\begin{tabular}{|c|c|c|c|c|}
\hline $\begin{array}{l}\text { Year } \\
\text { (month) }\end{array}$ & Country & Site & $\begin{array}{l}\text { Chronology } \\
\text { / Period }\end{array}$ & $\begin{array}{l}\text { Mission } \\
\text { (project manager) }\end{array}$ \\
\hline $\begin{array}{l}1993 \\
\text { Dec. }\end{array}$ & Sudan & El Gadar & Stone Age & $\begin{array}{l}\text { Royal Ontario Museum Canada } \\
\text { Chris Grzymski }\end{array}$ \\
\hline $\begin{array}{l}1993 \\
\text { Dec. }\end{array}$ & Sudan & Kasura & Stone Age & $\begin{array}{l}\text { British Museum } \\
\text { Derek Welsby }\end{array}$ \\
\hline 1994 & Sudan & $\begin{array}{l}\text { El Gaddar, Hambukol - } \\
\text { Gebel Kobkabba } \\
\text { (Old Dongola Area) }\end{array}$ & Palaeolithic & $\begin{array}{l}\text { Royal Ontario Museum Canada } \\
\text { Chris Grzymski }\end{array}$ \\
\hline $\begin{array}{l}1996 \\
\text { Aug.-Nov. }\end{array}$ & Egypt & Sinai & $\begin{array}{l}\text { Palaeolithic, } \\
\text { Neolithic, } \\
\text { Bronze Age }\end{array}$ & $\begin{array}{l}\text { CPE } \\
\text { Central Sinai Salvage Project } \\
\text { Fred Wendorf and Romuald Schild }\end{array}$ \\
\hline $\begin{array}{l}1999 \\
\text { Aug., Sep. }\end{array}$ & Botswana & $\begin{array}{l}\text { Study - survey } \\
\text { Gabarone, Maun, } \\
\text { Okawango Delta, } \\
\text { Makadikadi, Palapie }\end{array}$ & Prehistory & IAE PAS \\
\hline $\begin{array}{l}1999 \\
\text { Nov., Dec. }\end{array}$ & Sudan & $\begin{array}{l}\text { Conference of UISPP } \\
\text { Commission - } \\
\text { Khartoum, Naga }\end{array}$ & - & IAE PAS \\
\hline $\begin{array}{l}2000 \\
\text { Jan.-Mar. }\end{array}$ & Egypt & $\begin{array}{l}\text { Gebel Nabta } \\
\text { (Western Desert) }\end{array}$ & Neolithic & $\begin{array}{l}\text { CPE } \\
\text { Romuald Schild and Fred Wendorf }\end{array}$ \\
\hline $\begin{array}{l}2000 \\
\text { Nov., Dec. }\end{array}$ & Egypt & $\begin{array}{l}\text { Dakhleh Oasis, } \\
\text { Ain El Gazzereen }\end{array}$ & $\begin{array}{l}\text { Rock art, Archaic } \\
\text { Old Kingdom }\end{array}$ & $\begin{array}{l}\text { PCMA/DOP-PU } \\
\text { Lech Krzyżaniak }\end{array}$ \\
\hline $\begin{array}{l}2001 \\
\text { Jan.-Mar. }\end{array}$ & Egypt & $\begin{array}{l}\text { Gebel Ramlah } \\
\text { (Western Desert) }\end{array}$ & Neolithic & $\begin{array}{l}\text { CPE } \\
\text { Romuald Schild and Fred Wendorf }\end{array}$ \\
\hline $\begin{array}{l}2001 \\
\text { Nov., Dec. }\end{array}$ & Sudan & Kadero & Neolithic & $\begin{array}{l}\text { PCMA } \\
\text { Lech Krzyżaniak }\end{array}$ \\
\hline $\begin{array}{l}2003 \\
\text { Jan., Feb. }\end{array}$ & Egypt & $\begin{array}{l}\text { Gebel Ramlah } \\
\text { (Western Desert) }\end{array}$ & Neolithic & $\begin{array}{l}\text { CPE } \\
\text { Romuald Schild and Fred Wendorf }\end{array}$ \\
\hline $\begin{array}{l}2003 \\
\text { Mar. }\end{array}$ & Egypt & $\begin{array}{l}\text { Dakhleh Oasis, } \\
\text { Ain El Gazzereen }\end{array}$ & $\begin{array}{l}\text { Rock art, Archaic } \\
\text { Old Kingdom }\end{array}$ & $\begin{array}{l}\text { PCMA/DOP-PU } \\
\text { Lech Krzyżaniak }\end{array}$ \\
\hline $\begin{array}{l}2003 \\
\text { Nov. }\end{array}$ & Sudan & $\begin{array}{l}\text { Survey on the IVth Nile } \\
\text { Cataract and Bayuda Desert }\end{array}$ & Prehistory & $\begin{array}{l}\text { PCMA/ Poznan Archaeological } \\
\text { Museum } \\
\text { Lech Krzyżaniak }\end{array}$ \\
\hline $\begin{array}{l}2004 \\
\text { Jul., Aug. }\end{array}$ & Tanzania & $\begin{array}{l}\text { Loyangalani } \\
\text { (Serengeti National Park) }\end{array}$ & Palaeolithic & $\begin{array}{l}\text { Serengeti Foundation (US) } \\
\text { John R. F. Bower }\end{array}$ \\
\hline
\end{tabular}


$22 \mid$ Przemystaw Bobrowski

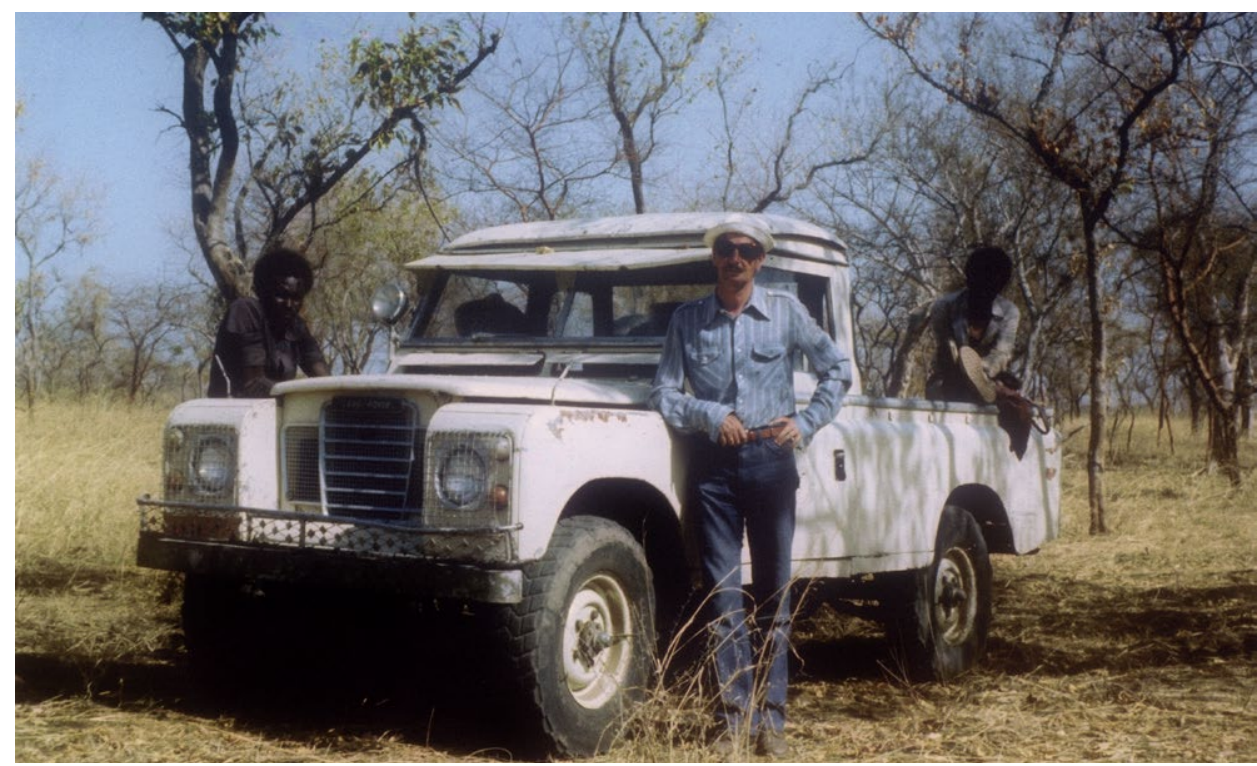

Fig. 5. SE Sudan near Abu Hugar. Survey along the banks of the Blue Nile. Photo: L. Krzyżaniak.

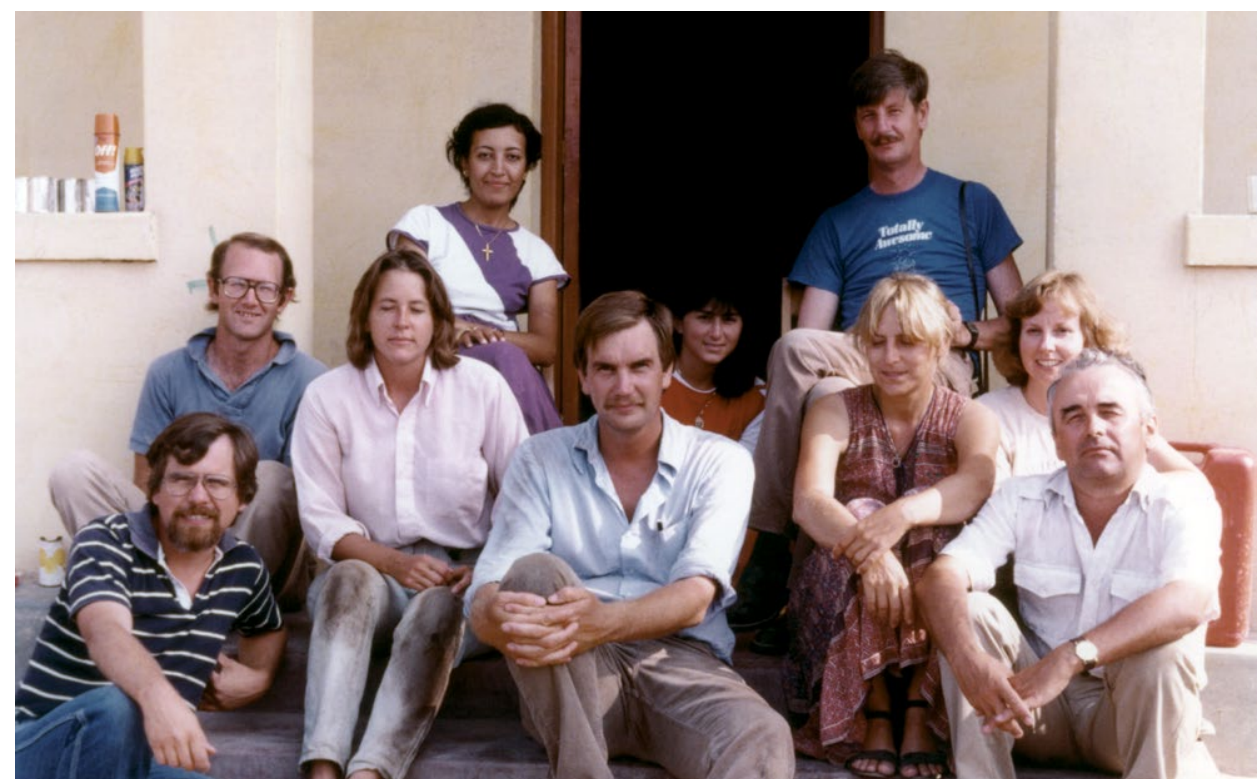

Fig. 6. Kom El-Hisn in the Western Delta, Egypt (1986). Bottom row from the left: Anthony Cegle, Janet Long, Robert Wenke, Karla Kroeper, Willma Wetterstrom, Lech Krzyżaniak. Upper row from the left: Inspector Samicha and Michał Kobusiewicz. Photo: M. Kobusiewicz, private collection. 


\begin{tabular}{|c|c|c|c|c|}
\hline $\begin{array}{l}\text { Year } \\
\text { (month) }\end{array}$ & Country & Site & $\begin{array}{l}\text { Chronology } \\
\text { / Period }\end{array}$ & $\begin{array}{l}\text { Mission } \\
\text { (project manager) }\end{array}$ \\
\hline $\begin{array}{l}2005 \\
\text { Feb., Mar. }\end{array}$ & Egypt & $\begin{array}{l}\text { Dakhleh Oasis, } \\
\text { Ain El Gazzereen }\end{array}$ & $\begin{array}{l}\text { Rock art, Archaic } \\
\text { Old Kingdom }\end{array}$ & $\begin{array}{l}\text { PCMA/DOP-PU } \\
\text { Michał Kobusiewicz }\end{array}$ \\
\hline $\begin{array}{l}2005 \\
\text { Jul., Aug. }\end{array}$ & Tanzania & Serengeti National Park & Palaeolithic & $\begin{array}{l}\text { Serengeti Foundation (US) } \\
\text { John R. F. Bower }\end{array}$ \\
\hline $\begin{array}{l}2006 \\
\text { Feb., Mar. }\end{array}$ & Egypt & $\begin{array}{l}\text { Dakhleh Oasis, } \\
\text { Ain El Gazzereen }\end{array}$ & $\begin{array}{l}\text { Rock art, Archaic } \\
\text { Old Kingdom }\end{array}$ & $\begin{array}{l}\text { PCMA/DOP-PU } \\
\text { Michał Kobusiewicz }\end{array}$ \\
\hline $\begin{array}{l}2006 \\
\text { Jun. }\end{array}$ & Egypt & $\begin{array}{l}\text { Conference of Dakhleh } \\
\text { Oasis Project - Cairo }\end{array}$ & & PCMA/IAE PAS \\
\hline $\begin{array}{l}2007 \\
\text { Feb., Mar. }\end{array}$ & Egypt & $\begin{array}{l}\text { Dakhleh Oasis, } \\
\text { Ain El Gazzereen }\end{array}$ & $\begin{array}{l}\text { Rock art, Archaic } \\
\text { Old Kingdom }\end{array}$ & $\begin{array}{l}\text { PCMA/DOP-PU } \\
\text { Michał Kobusiewicz }\end{array}$ \\
\hline $\begin{array}{l}2007 \\
\text { Sep. }\end{array}$ & Egypt & $\begin{array}{l}\text { Conference " } 70 \text { Years of } \\
\text { Polish Archaeology in } \\
\text { Egypt" - Cairo }\end{array}$ & & PCMA \\
\hline $\begin{array}{l}2008 \\
\text { Jan., Feb. }\end{array}$ & Egypt & $\begin{array}{l}\text { Dakhleh Oasis, } \\
\text { Ain El Gazzereen }\end{array}$ & $\begin{array}{l}\text { Rock art, Archaic } \\
\text { Old Kingdom }\end{array}$ & $\begin{array}{l}\text { PCMA/ DOP-PU } \\
\text { Michał Kobusiewicz }\end{array}$ \\
\hline $\begin{array}{l}2008 \\
\text { Nov., Dec. }\end{array}$ & Egypt & $\begin{array}{l}\text { Dakhleh Oasis, } \\
\text { Ain El Gazzereen }\end{array}$ & $\begin{array}{l}\text { Rock art, Archaic } \\
\text { Old Kingdom }\end{array}$ & $\begin{array}{l}\text { PCMA/DOP_PU } \\
\text { Michał Kobusiewicz }\end{array}$ \\
\hline $\begin{array}{l}2009 \\
\text { Nov., Dec. }\end{array}$ & Egypt & $\begin{array}{l}\text { Dakhleh Oasis, } \\
\text { Ain El Gazzereen Siwa } \\
\text { Oasis }\end{array}$ & $\begin{array}{l}\text { Rock art, Archaic } \\
\text { Old Kingdom, } \\
\text { Prehistory }\end{array}$ & $\begin{array}{l}\text { PCMA/DOP-PU } \\
\text { Michał Kobusiewicz }\end{array}$ \\
\hline $\begin{array}{l}2010 \\
\text { Feb., Mar. }\end{array}$ & Egypt & $\begin{array}{l}\text { Study and Conservation } \\
\text { Visit - Aswan } \\
\text { (Nubian Museum) }\end{array}$ & Neolithic & CPE Foundation (US) \\
\hline $\begin{array}{l}2010 \\
\text { Oct. }\end{array}$ & Egypt & $\begin{array}{l}\text { Study Visit - } \\
\text { Cairo }\end{array}$ & $\begin{array}{l}\text { Archaic } \\
\text { Old Kingdom }\end{array}$ & IAE PAS \\
\hline $\begin{array}{l}2010 \\
\text { Nov., Dec. }\end{array}$ & Sudan & $\begin{array}{l}\text { Bir Nurayet } \\
\text { (Red Sea Hill) }\end{array}$ & Rock art, Prehistory & $\begin{array}{l}\text { IAE PAS } \\
\text { Bir Nurayet Project } \\
\text { Przemysław Bobrowski }\end{array}$ \\
\hline $\begin{array}{l}2011 \\
\text { Feb. }\end{array}$ & Egypt & $\begin{array}{l}\text { Dakhleh Oasis, } \\
\text { Siwa Oasis }\end{array}$ & Rock art, Prehistory & $\begin{array}{l}\text { PCMA/DOP-PU } \\
\text { Michał Kobusiewicz }\end{array}$ \\
\hline $\begin{array}{l}2011 \\
\text { Mar. }\end{array}$ & Egypt & $\begin{array}{l}\text { Study Visit - } \\
\text { Cairo }\end{array}$ & $\begin{array}{l}\text { Archaic } \\
\text { Old Kingdom }\end{array}$ & PCMA \\
\hline
\end{tabular}


24

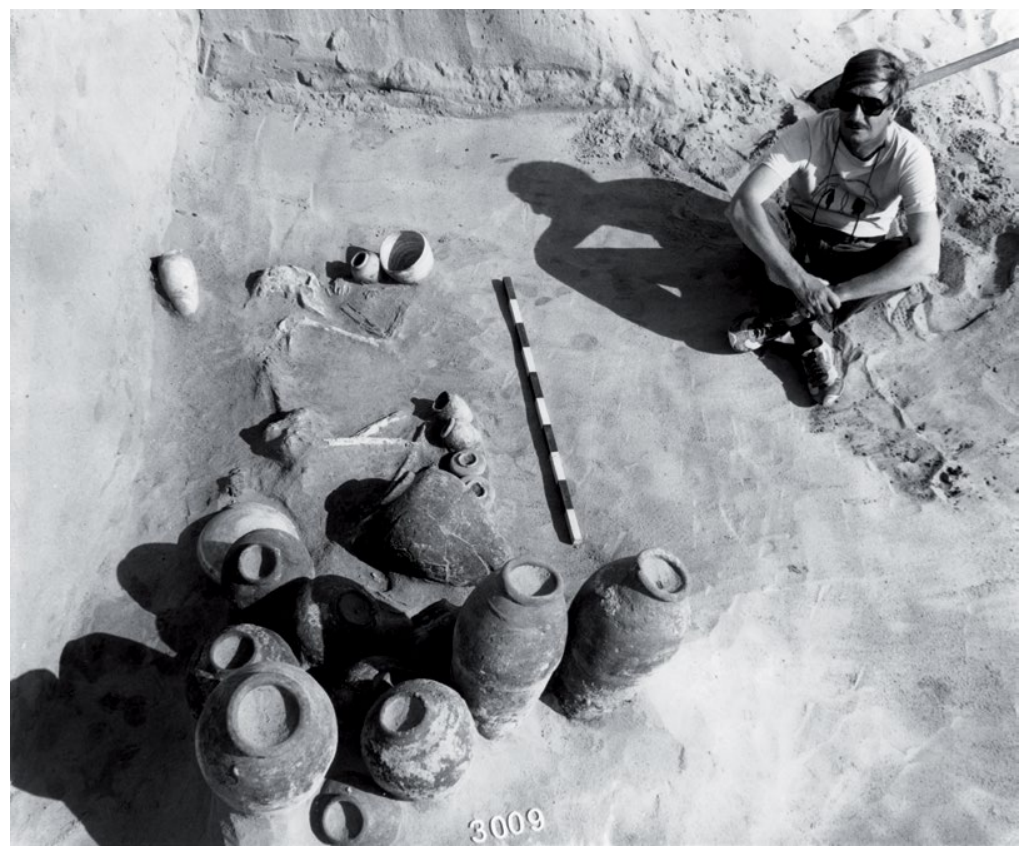

Fig. 7. Minshat Abu Omar, in the Eastern Delta, Egypt (1988). Michał Kobusiewicz during the excavation of a Predynastic grave. Photo: M. Kobusiewicz, private collection.

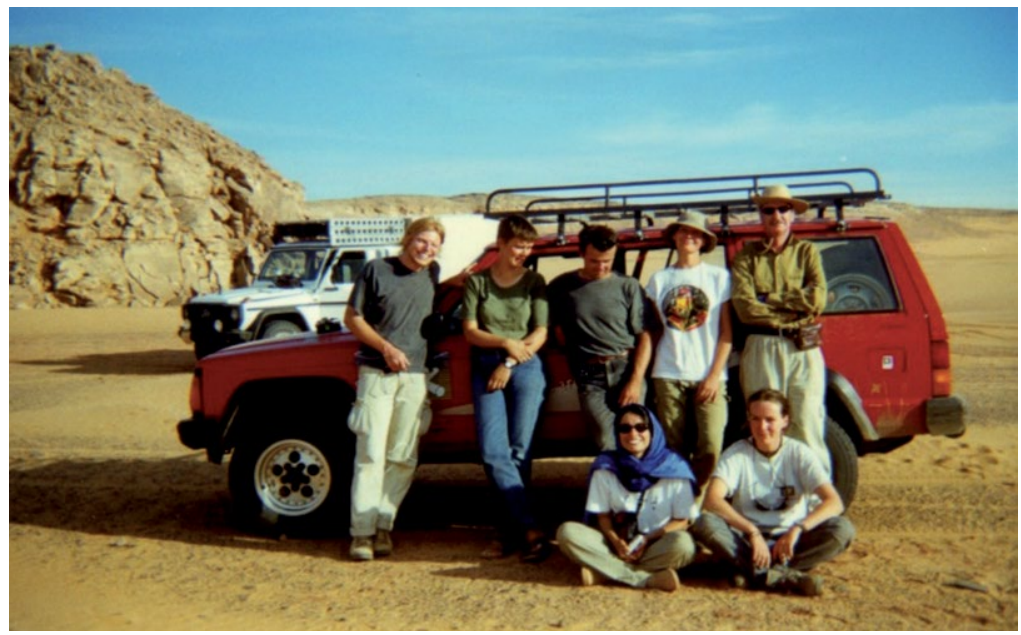

Fig. 8. Dakhleh Oasis, Egypt (2000). Standing, from the left: Heiko Riemer, Karin Kindermann, a member of the German team, Eliza Jaroni, Michał Kobusiewicz. Sitting: Sofia, a student from Portugal and Ewa Kuciewicz. Photo: M. Kobusiewicz, private collection. 


\begin{tabular}{|c|c|c|c|c|}
\hline $\begin{array}{l}\text { Year } \\
\text { (month) }\end{array}$ & Country & Site & $\begin{array}{l}\text { Chronology } \\
\text { / Period }\end{array}$ & $\begin{array}{l}\text { Mission } \\
\text { (project manager) }\end{array}$ \\
\hline $\begin{array}{l}2011 \\
\text { Mar., Apr. }\end{array}$ & Sudan & $\begin{array}{l}\text { Conference - } \\
\text { "Fifty Years of Cooperation } \\
\text { between Sudan and } \\
\text { Poland in the Field of } \\
\text { Archaeology"- Khartoum }\end{array}$ & & PCMA \\
\hline $\begin{array}{l}2011 \\
\text { Nov., Dec. }\end{array}$ & Sudan & $\begin{array}{l}\text { Bir Nurayet } \\
\text { Red Sea Hill }\end{array}$ & Rock art, Prehistory & $\begin{array}{l}\text { IAE PAS } \\
\text { Bir Nurayet Project } \\
\text { Przemysław Bobrowski }\end{array}$ \\
\hline $\begin{array}{l}2012 \\
\text { Feb. }\end{array}$ & Egypt & $\begin{array}{l}\text { Dakhleh Oasis, } \\
\text { Siwa Oasis }\end{array}$ & Rock art, Prehistory & $\begin{array}{l}\text { PCMA/DOP-PU } \\
\text { Michał Kobusiewicz }\end{array}$ \\
\hline $\begin{array}{l}2012 \\
\text { Mar. }\end{array}$ & Egypt & $\begin{array}{l}\text { Study Visit - } \\
\text { Cairo }\end{array}$ & $\begin{array}{l}\text { Archaic } \\
\text { Old Kingdom }\end{array}$ & PCMA \\
\hline $\begin{array}{l}2012 \\
\text { Nov., Dec. }\end{array}$ & Sudan & $\begin{array}{l}\text { Bir Nurayet, Gebel } \\
\text { Karaiweb } \\
\text { (Red Sea Hill) }\end{array}$ & Rock art, Prehistory & $\begin{array}{l}\text { IAE PAS } \\
\text { Bir Nurayet Project } \\
\text { Przemysław Bobrowski }\end{array}$ \\
\hline $\begin{array}{l}2013 \\
\text { Feb. }\end{array}$ & Egypt & Dakhleh Oasis & Rock art, Prehistory & $\begin{array}{l}\text { PCMA/DOP-PU } \\
\text { Michał Kobusiewicz }\end{array}$ \\
\hline $\begin{array}{l}2013 \\
\text { Mar. }\end{array}$ & Egypt & $\begin{array}{l}\text { Study Visit - } \\
\text { Cairo }\end{array}$ & $\begin{array}{l}\text { Archaic } \\
\text { Old Kingdom }\end{array}$ & PCMA \\
\hline $\begin{array}{l}2016 \\
\text { May }\end{array}$ & Egypt & $\begin{array}{l}\text { Study Visit - } \\
\text { Cairo }\end{array}$ & Neolithic & $\begin{array}{l}\text { IAE PAS } \\
\text { Bargat El-Shab Project } \\
\text { Michał Kobusiewicz } \\
\text { and Przemysław Bobrowski }\end{array}$ \\
\hline $\begin{array}{l}2017 \\
\text { Mar. }\end{array}$ & Egypt & $\begin{array}{l}\text { Study Visit - } \\
\text { Cairo, Aswan }\end{array}$ & Neolithic & $\begin{array}{l}\text { IAE PAS } \\
\text { Bargat El-Shab Project } \\
\text { Michał Kobusiewicz and } \\
\text { Przemysław Bobrowski }\end{array}$ \\
\hline $\begin{array}{l}2018 \\
\text { Apr. }\end{array}$ & Egypt & $\begin{array}{l}\text { Bargat El-Shab } \\
\text { (Western Desert) }\end{array}$ & Neolithic & $\begin{array}{l}\text { IAE PAS } \\
\text { Bargat El-Shab Project } \\
\text { Michał Kobusiewicz } \\
\text { and Przemysław Bobrowski }\end{array}$ \\
\hline
\end{tabular}


$26 \mid$ Przemystaw Bobrowski

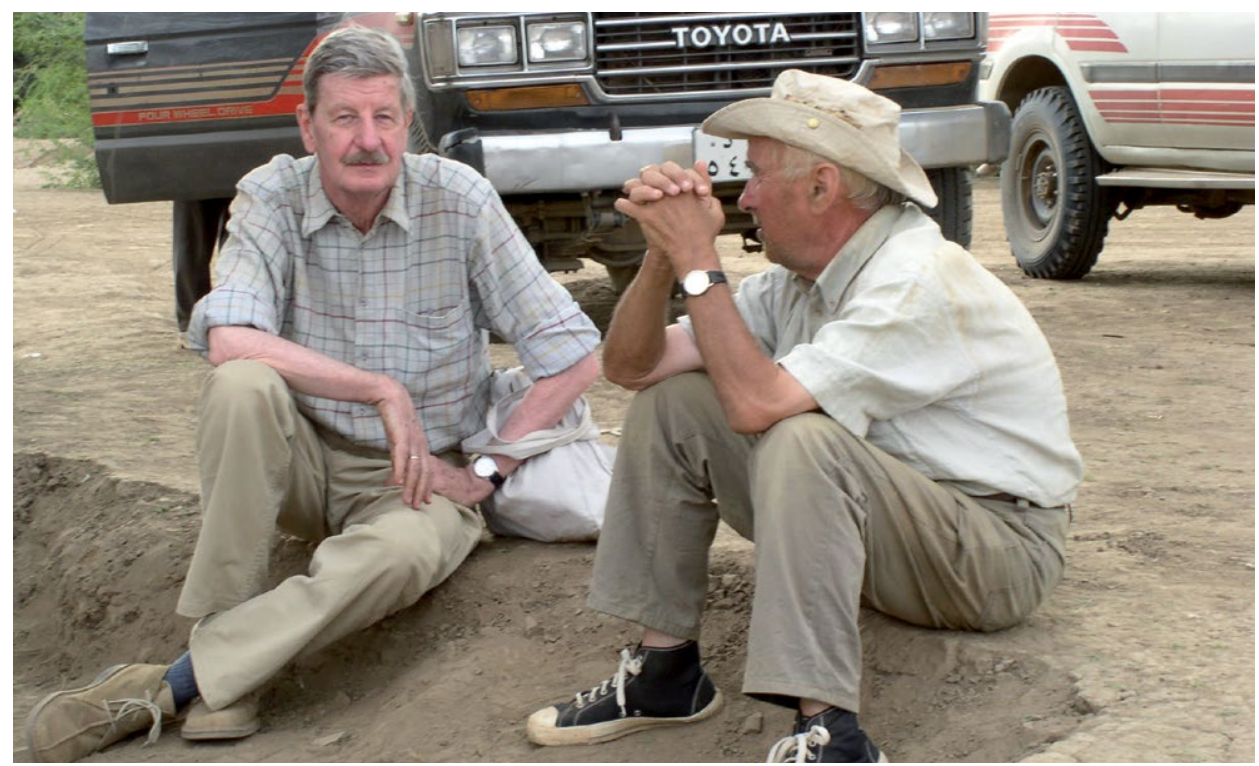

Fig. 9. Atbara, Sudan (2003). Michał Kobusiewicz with his great friend Lech Krzyżaniak waiting to be taken across the Nile. Photo: M. Jórdeczka.

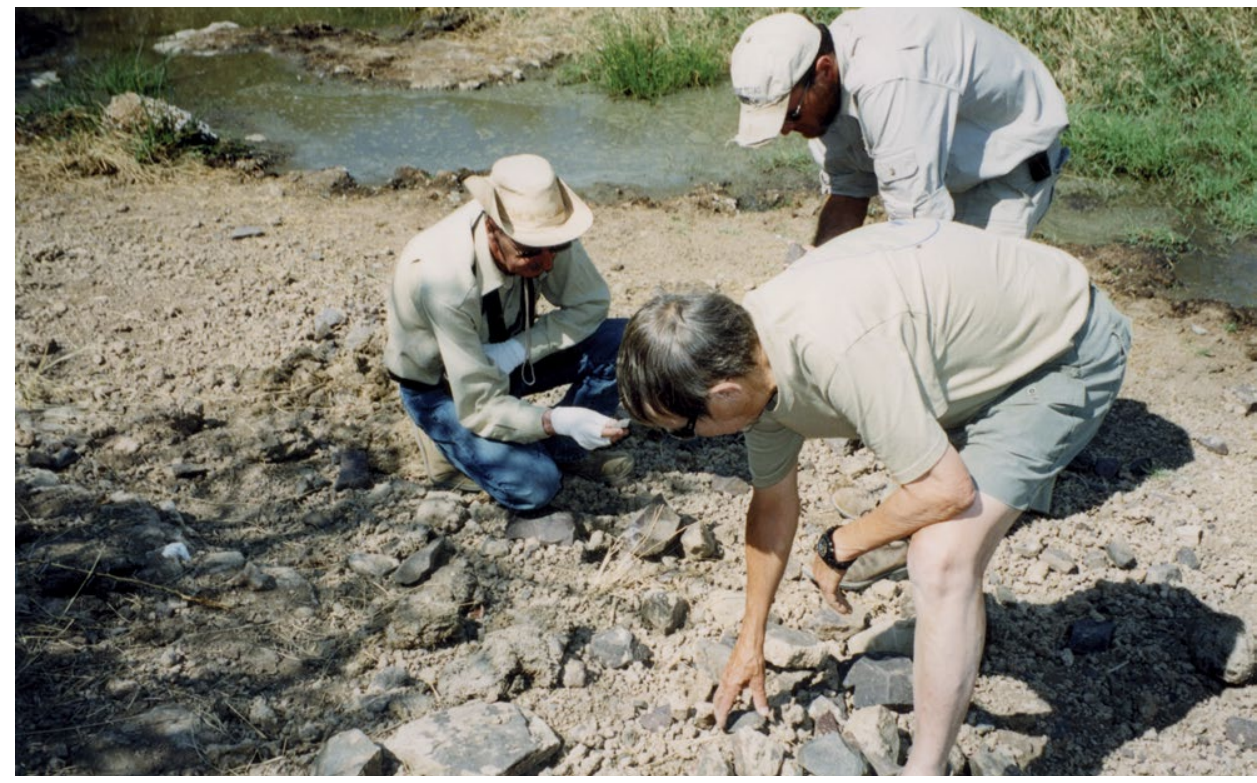

Fig. Io. Serengeti, Tanzania (2005). During an archaeological survey. From the left: Michał Kobusiewicz, Adax Mabulla and John R. F. Bower. Photo: M. Kobusiewicz, private collection. 


\section{AFRICAN BIBLIOGRAPHY OF MICHAE KOBUSIEWICZ}

\section{2}

Preliminary report on the Holocene geology and archaeology of the Northern Fayum Desert. In Playa Lake Symposium. Icaslas publications 4: 4I-6I [with R. Said, C. Albritton, F. Wendorf and R. Schild].

Remarks on Holocene geology and archaeology of Northern Fayum Desert. Archeologia Polona 13: 7-22 [with R. Said, C. Albritton, F. Wendorf and R. Schild].

\section{6}

New prehistoric materials from the region of Old Dongola (Sudan). Fontes Archaeologici Posnanienses 25 [1974]: I78-I86 [with L. Krzyżaniak].

Pradzieje północno-wschodniej Afryki między I6 a 5 tysiącleciem p.n.e. Przegląd Archeologiczny 24: 5-IOI. The Prehistory of the Egyptian Sahara. Science I93(4248): I05-II4 [with F. Wendorf, R. Schild, R. Said, C. V. Haynes and A. Gautier].

\section{7}

Late Pleistocene and recent climatic changes in Egyptian Sahara. Geographical Journal I43(2): 2II-234 [with F. Wendorf, R. Schild, R. Said, C. V. Haynes, A. Gautier, N. el Hadidi, H. Więckowska and A. Close].

\section{8}

A voice in the discussion connected with the paper by R. Schild and F. Wendorf, Wieloznaczność ekologicznego uwarunkowania, wielkich zmian kulturowych. Dwa przykłady: Niż Europejski u schyłku epoki lodowej i Sahara w początkach holocenu. Przeglad Antropologiczny 44(I): 2II-2I2.

\section{9}

Combined Prehistoric Expedition. Z Otchtani Wieków 45(I): 2-II.

Use of barley in the Egyptian Late Palaeolithic. Science 205(44I3): I34I-I347 [with F. Wendorf, R. Schild, N. el Hadidi, A. E. Close, H. Więckowska, B. Issawi and H. Haas].

\section{0}

Badania Combined Prehistoric Expedition w Egipcie i Sudanie. In M. Kobusiewicz and L. Krzyżaniak (eds), Epoka kamienia nad Nilem: przewodnik po wystawie, IO-I4. Poznań.

Report on Site E-78-2. In F. Wendorf and R. Schild, assemblers, and A. E. Close (ed.), Loaves and Fishes: The prehistory of Wadi Kubbaniya, 55-75. Dallas [with K. M. Banks].

Report on Site E-78-9. In F. Wendorf and R. Schild, assemblers, and A. E. Close (ed.), Loaves and Fishes: The prehistory of Wadi Kubbaniya, 19I-215. Dallas [with W. L. Singleton].

I-er symposium international: Genése et premières phases du développement de la production alimentai dans les cultures préhistoriques du nordest de l'Afrique 9-13 Septembre 1980: Dymaczewo pres de Poznań, Pologne. L'Antropologie 84(5): 468-470.

Problemy neolityzacji Afryki północno-wschodniej. Sprawozdania: 42(96) [1978] 4-5. Wydział Historii i Nauk Społecznych PTPN.

Der Übergang vom Spätpaläolithikum zum Neolithikum in Nordostafrika. Allgemeine und Vergleichende Archäologie - Beiträge 2: 337-350. 
$28 \mid$ Przemystaw Bobrowski

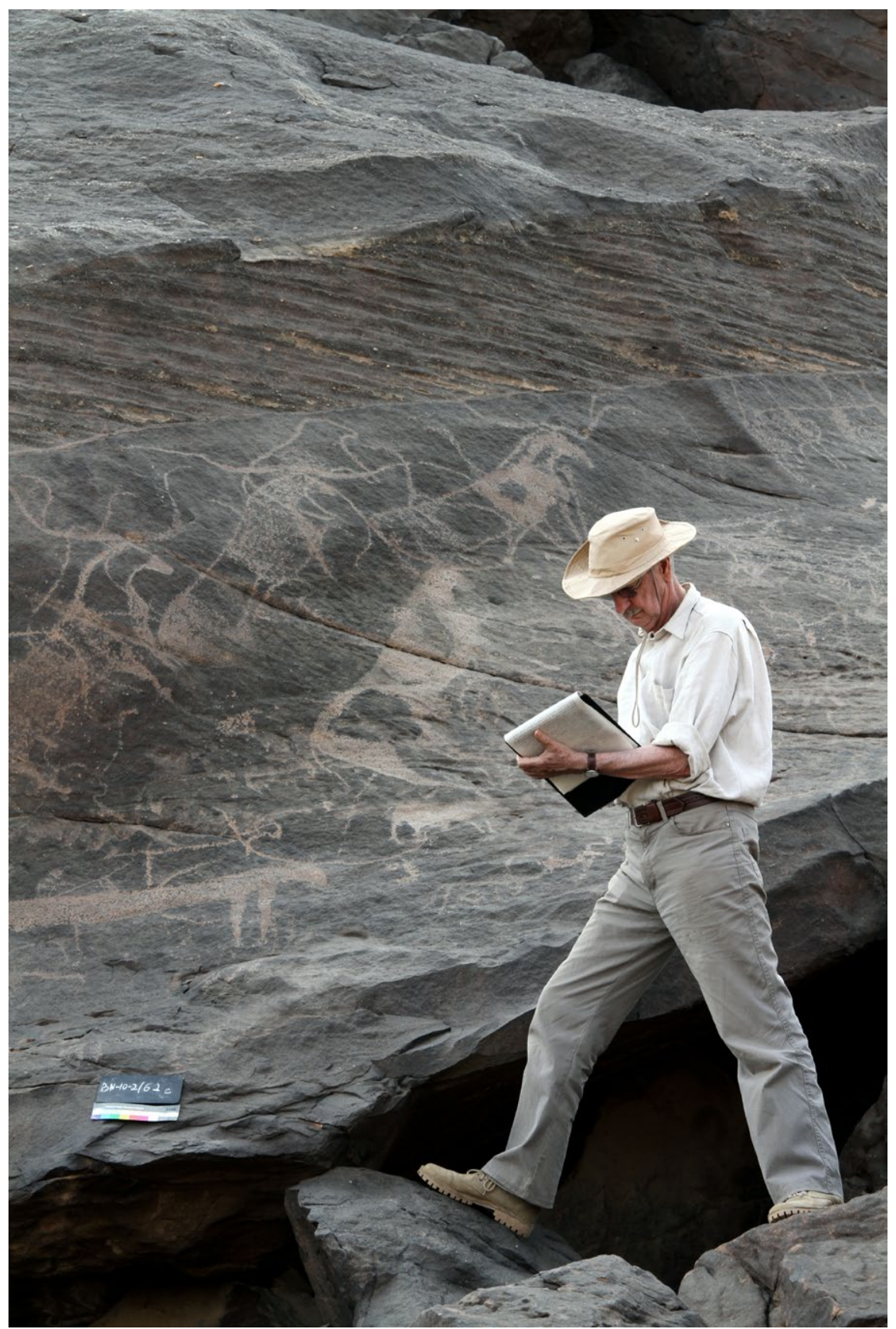

Fig. II. Bir Nurayet in the mountains by the Red Sea (2010). Documentation of rock art. Photo: M. Jórdeczka. 


\section{1}

Nowe poglądy na zagadnienia neolityzacji północno-wschodniej Afryki. Przegląd Archeologiczny 28: 177-185.

R. Schild and F. Wendorf, The Prehistory of an Egyptian Oasis. Wrocław, Warszawa, Kraków, Gdańsk, Łódź, Zakład Narodowy imienia Ossolińskich, Wydawnictwo Naukowe Polskiej Akademii Nauk [as contributor together with C. V. Haynes, J. Kossakowska-Such, R. Said, T. Wesołowska, O. Henderson and R. Morrison].

\section{2}

Research at Bir Tarfawi: Archaeological and Geological Investigations in the Egyptian Sahara. Archaeologia Polona 20 [198I]: 177-198 [with F. Wendorf, R. Schild, R. Said and A. Gautier].

\section{4}

The multicultural Early Holocene site E-79-4 at El Ghorab Playa, Western Desert of Egypt. In L. Krzyżaniak and M. Kobusiewicz (eds), Orgin and early development of food-producing cultures in North Eastern Africa, I7I-I84. Poznań.

Report on Site E-79-4. The archaeology of El Ghorab Playa. In A. E. Close, F. Wendorf and R. Schild (eds), Cattle-keepers of Eastern Sahara: the Neolithic of Bir Kiseiba, I35-164. New Delhi.

New radiocarbon dates on the cereals from Wadi Kubbaniya. Science 225(4662): 645-646 [with F. Wendorf, R. Schild, A. E. Close, D. J. Donahue, A. J. T. Jull, T. H. Zabel, H. Więckowska, M. Kobusiewicz, B. Issawi and N. el Hadidi].

\section{7}

The Combined Prehistoric Expedition. The first twenty-five years. In A. E. Close (ed.), Prehistory of arid North Africa. Essays in honor of Fred Wendorf, 325-344. Dallas.

\section{9}

Report on Site E-78-9: An early Kubbaniyan Site in the Mouth of Wadi Kubbaniya. In F. Wendorf and R. Schild, assemblers, and A. E. Close (ed.), The Prehistory of Wadi Kubbaniya. Vol. 3: Late Palaeolithic Archaeology, 643-653. Dallas.

Report on Site E-78-5: A Kubbaniyan Site near the Mouth of Wadi Kubbaniya. In F. Wendorf and R. Schild, assemblers, and A. E. Close (ed.), The Prehistory of Wadi Kubbaniya. Vol. 3: Late Palaeolithic Archaeology, 654-665. Dallas.

Report on Site E-78-5e: A Small Ballanan-Silsilian Site near the Mouth of Wadi Kubbaniya. In F. Wendorf and R. Schild, assemblers, and A. E. Close (ed.), The Prehistory of Wadi Kubbaniya. Vol. 3: Late Palaeolithic Archaeology, 669-674. Dallas.

Report on Site E-78-5f: An Apparent Single-Occupation Site near the Mouth of Wadi Kubbaniya. In In F. Wendorf and R. Schild, assemblers, and A. E. Close (ed.), The Prehistory of Wadi Kubbaniya. Vol. 3: Late Palaeolithic Archaeology, 675-678. Dallas.

Kom el-Hisn: Excavations of Old Kingdom Settlement in Egyptian Delta. Journal of American Research Center in Egypt 25 (1988): 5-34 [with R. Wenke, P. Buck, H. Hamroush, K. Kroeper and R. W. Redding].

\section{2 (1991)}

Review of F. Debono and B. Mortensen, A Neolithic settlement and Rother sites in vicinity of Wadi Hof, Helwan, Mainz 1990. Archeologia 42: 153.

Review of J. Rizkana and J. Seeher, The Predynastic cemeteries of Maadi and Wadi Digla. Mainz 1990. Archeologia 42: 153-I54. 
$30 \mid$ Przemystaw Bobrowski

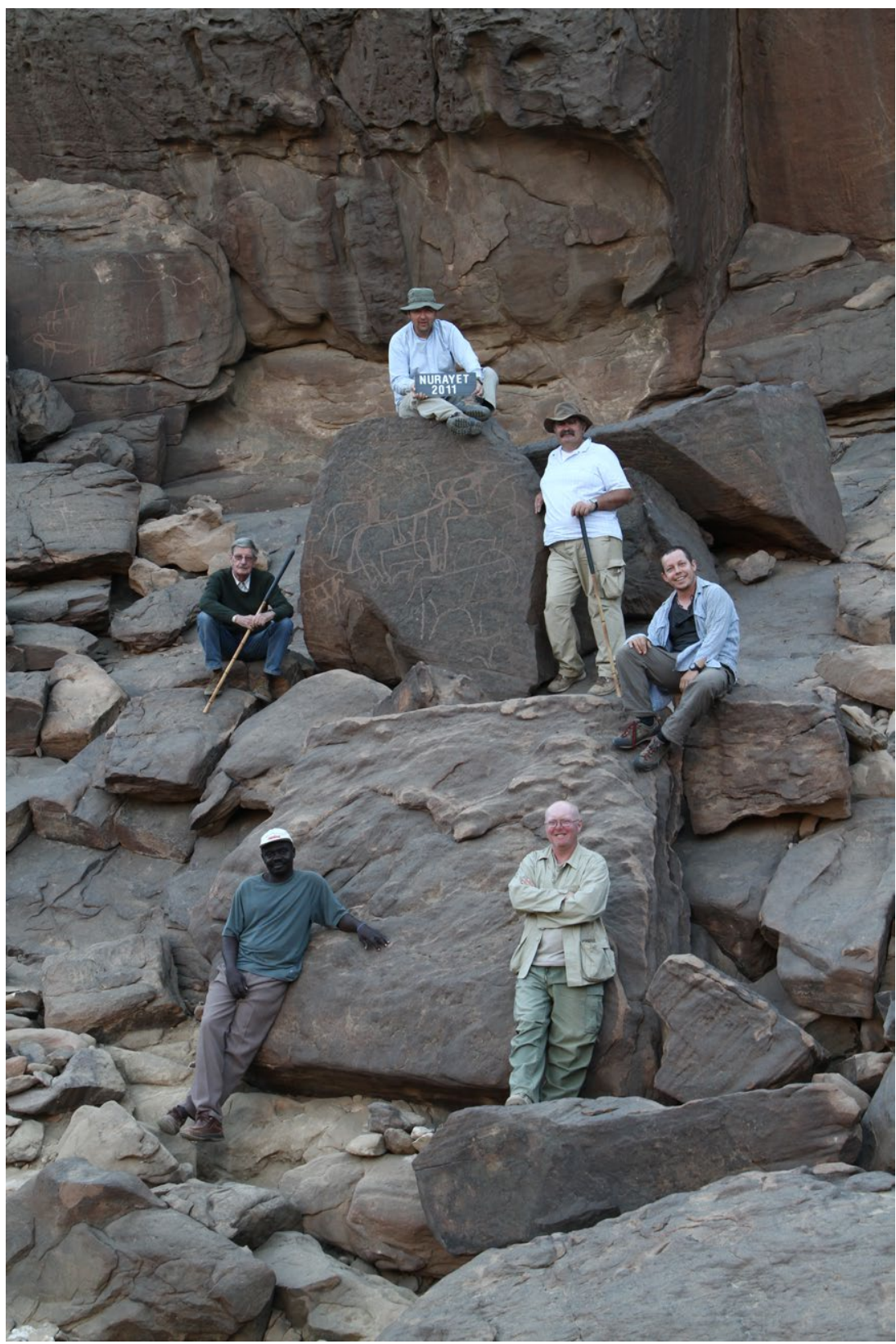

Fig. 12. Bir Nurayet in the mountains by the Red Sea (2OII). In the lower row: from the left, NCAM Inspector Tayeb and Paweł Wiktorowicz. In the middle row: Michał Kobusiewicz, Marek Chłodnicki and Maciej Jórdeczka. Przemysław Bobrowski sitting on a stone. Photo: M. Jórdeczka (self-timer). 


\section{4}

Discovery of Middle Stone Age sites near El Ghaddar (Sudan). Nyame Akuma 4I: 63-66.

Review of J. Einwanger, Merimde-Benisalam III. Die Funde der jüngeren Merimde-Kultur. Mainz I992. Archaeologia 44 (1993): I3I.

\section{6}

Technology, goals and efficiency of quartz exploitation in Khartoum Neolithic: case of Kadero. In L. Krzyżaniak, K. Kroeper and M. Kobusiewicz (eds), Interregional contacts in the Later Prehistory of Northeastern Africa, 347-364. Poznań.

Jebbel Kobkabba: a Middle Palaeolithic site in Sudanese Nubia. In L. Krzyżaniak, K. Kroeper and M. Kobusiewicz (eds), Interregional contacts in the Later Prehistory of Northeastern Africa, 355-375. Poznań [with J. Kabaciński].

\section{7}

Late Pleistocene settlement in the Mediterranean Littoral of Northeastern Africa after last Pleniglacial. In J. M. Fullola and N. Soler (eds), El món mediterrani després del Pleniglacial (I8.000-I2.000 BP), 93-97. Série Monogràfica 17.

\section{8}

Trend in stone knapping technology in Late Prehistory of Sudanese Nubia. In Actes de la VIII Conférence Internationale des Études Nubiennes Lille II-I7 Septembre 1994. 3 Etudes, I2I-I25. Lille. Cahires de Recherches de l'Institut de Papyrologie et d'Egyptologie de Lille No I7.

\section{9}

Excavations at Sinai-10, The Site Romythi Locality. In F. W. Eddy and F. Wendorf (eds), An Archaeological Investigation of the Central Sinai, Egypt, I73-180. Dallas.

Excavations at Sinai-20, The Split Rock Site, Zarnoq Locality. In F. W. Eddy and F. Wendorf (eds), An Archaeological Investigation of the Central Sinai, Egypt, 193-207. Dallas.

Excavations at Sinai-73, The Mazeyh Site, Zarnoq Locality. In F. W. Eddy and F. Wendorf (eds), An Archaeological Investigation of the Central Sinai, Egypt, 274-276. Dallas.

\section{0}

From the Organizers and Editors. In L. Krzyżaniak, K. Kroeper and M. Kobusiewicz (eds), Reccent Research Into the Stone Age of Northeastern Africa. Poznań Archaeological Museum. Studies in African Archaeology 7 [with L. Krzyżaniak, K. Kroeper].

\section{1}

Reassessing Chronostratigraphic Position of the Split Rock Site, Sinai. In B. Gehlen, M. Heinen and A. Tillmann (eds), Zeit Räume. Gedenkschrift für Wolfgang Taute, 227-236. Archäologische Berichte I4 [with R. Schild, A. Bluszcz and F. Wendorf].

Review of P. Vermeersch (ed.), Palaeolithic Living Sites in Upper and Middle Egypt. Egyptian Prehistory Monographs 2. Leuven University Press. Bibliotheca Orientalis 58(5-6): 604.

Afryka, Archeologia. In Wielka Encyklopedia PWN Tom I, I64-166. Warszawa, Wydawnictwo Naukowe PWN SA [with J. Kabaciński].

\section{2}

Gebel Ramlah Playa. In Jennerstrasse 8 (eds), Tides in the Desert-Gezeiten der Wüste, II7-I23. Köln [with R. Schild, F. Wendorf, J. D. Irish, J. Kabaciński and H. Królik]. 
32 Przemystaw Bobrowski

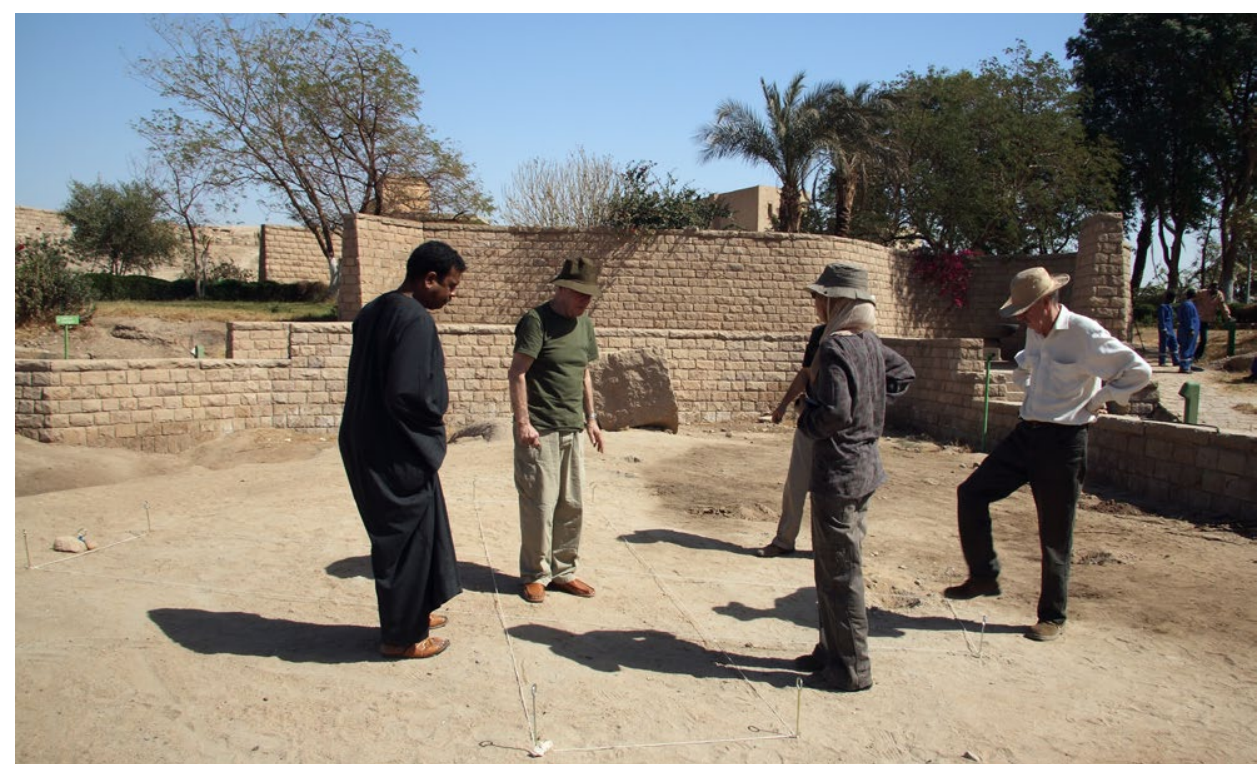

Fig. 13. Aswan, Egypt (20I2). Reconstruction of the megalithic "calendar" in the Nubian Museum. From the left: museum employee, Romuald Schild, Hebatallah A. A. Ibrahim and Michał Kobusiewicz. Photo: M. Jórdeczka.

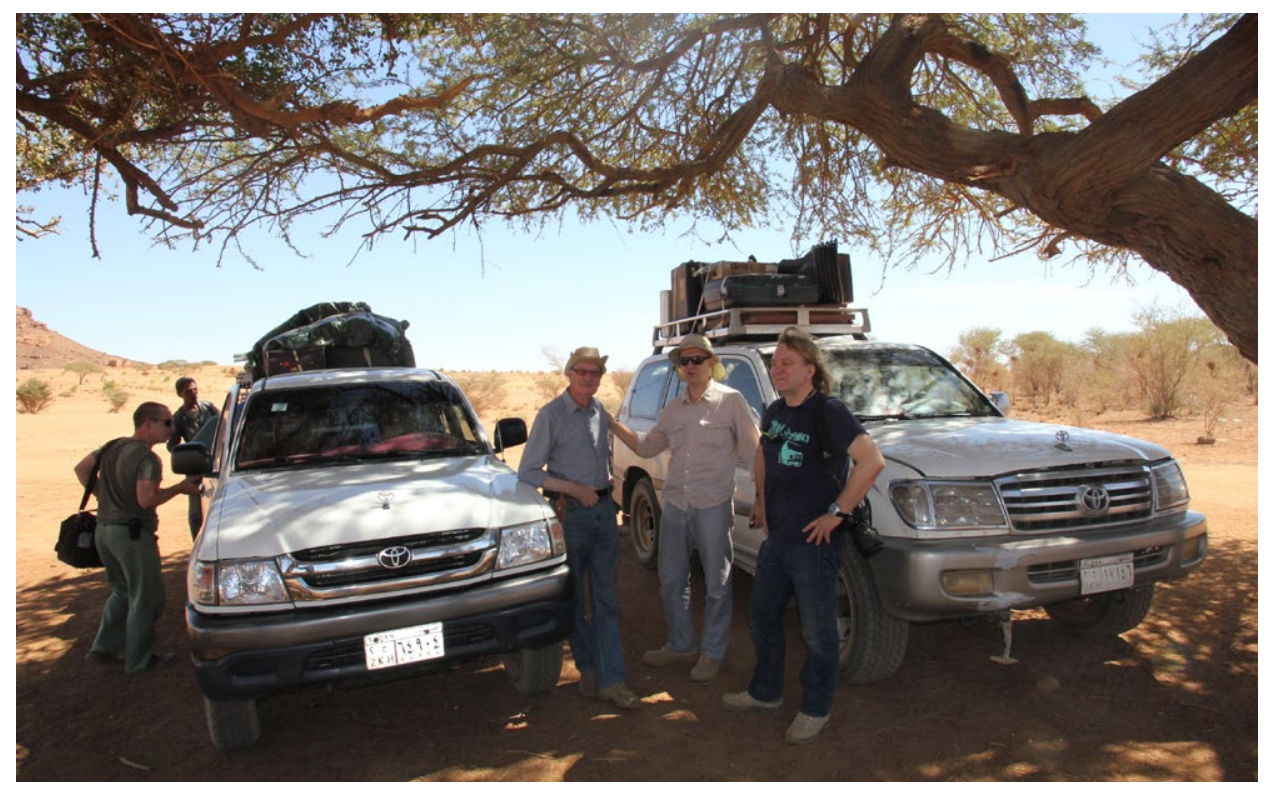

Fig. I4. Naga, Sudan (20I2). On the road to Bir Nurayet with sponsors of the mission. From the left: Michał Kobusiewicz, Maciej Korobacz and Jacek Jurek. Photo: P. Bobrowski. 


\section{3}

Neolithic Tooth Replacement in Two Disturbed Burials from Southern Egypt. Journal of Archaeological Science 30: 28I-285 [with J. D. Irish, R. Schild and F. Wendorf].

Neolithic wells of the Western Desert of Egypt. In L. Krzyżaniak, K. Kroeper and M. Kobusiewicz (eds), Cultural Markers in the Later Prehistory of Northeastern Africa and Recent Research, 95-IO4. Poznan, Poznań Archaeological Museum. Studies in African Archaeology 8.

\section{4}

An Artificial Human Tooth from the Neolithic Cemetery at Gebel Ramlah, Egypt. Dental Anthropology I7(I): 28-3I [with J. D. Irish, P. Bobrowski, J. Kabaciński and R. Schild].

Discovery of the first Neolithic cemetery in Egypt's Western Desert. Antiquity 78(301): 566-578 [with J. Kabaciński, R. Schild, J. D. Irish and F. Wendorf].

\section{5}

Short communication: Two additional Egyptian Neolithic burials exhibiting unusual mortuary treatment of teeth. International Journal of Osteoarchaeology 15: 136-139 [with J. D. Irish, M. Kobusiewicz, J. Kabaciński and R. Schild].

Prehistoric Herdsmen, Academia - The magazine of the Polish Academy of Sciences 3(7): 20-24 [with R. Schild]. Lech Krzyżaniak 1940-2004. Polish Archaeology in the Mediterranean I5: I3-I4.

Prof. Lech Krzyżaniak (1940-2004). In memoriam. Archaeologia Polona 43: 5-13.

Discovery of the Late Neolithic Cemetery in the Western Desert, Egypt. Gdańsk Archaeological Museum African Reports 3: 127-I29 [with J. Kabaciński, R. Schild and F. Wendorf].

New Important Area of Neolithic Occupation in the Southwestern Desert of Egypt. In B. E. Barich, T. Tillet and K. H. Stidter (eds), Hunters vs. Pastoralists in the Sahara Material Culture and Symbolic Aspects, 5I-56. British Archaeological Reports International Series 1338 [with R. Schild, F. Wendorf, J. D. Irish, J. Kabaciński, H. Królik and G. A. Calderoni].

\section{6}

Le paléolithique supérieur en Afrique du nord-est. In J. L. Sanchidrián, A. M. Márquez Alcántara and J. M. Fullola Pericot (eds), La Cuenca Meditteránea durante el Paleolítico Superior 38.000-10.000 años, I6-3r. Malaga.

Stone knapping tradition in Old Kingom Dakhleh. In K. Kroeper, M. Chłodnicki and M. Kobusiewicz (eds), Archaeology of Early Northeastern Africa. In Memory of Lech Krzyżaniak, 449-46I. Poznań, Poznań Archaeological Museum. Studies in African Archaeology 9.

\section{7}

The Petroglyph's Code. Academia - The magazine of the Polish Academy of Sciences I(I3): 4-8 [with E. Kuciewicz and E. Jaroni].

Dakhleh Oasis Petroglyph Unit. New rock art sites, season 2005. Polish Archaeology in the Mediterranean I7: 279-284 [with E. Kuciewicz and E. Jaroni].

\section{8}

Dakhleh Oasis Petroglyph Unit. Rock art research, 2006. Polish Archaeology in the Mediterranean I8 (2006): 317-322 [with E. Kuciewicz and E. Jaroni]. 
$34 \mid$ Przemystaw Bobrowski

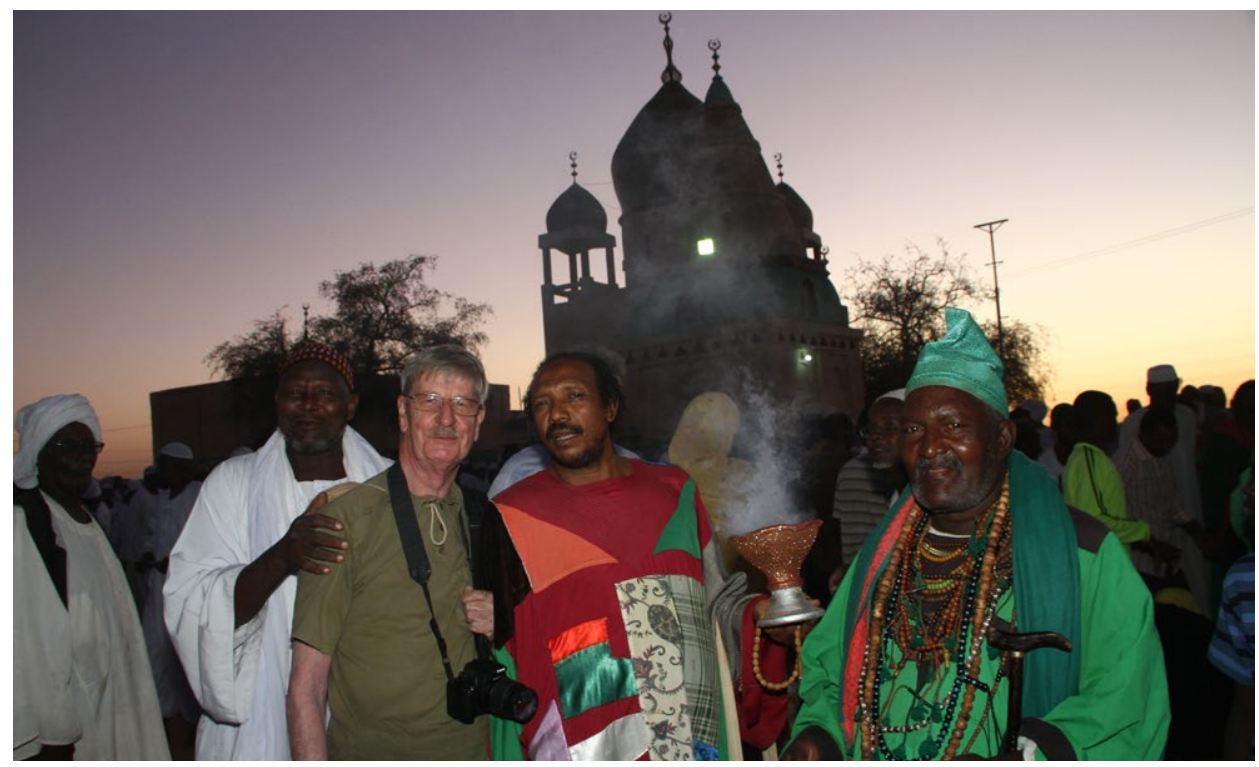

Fig. 15. Omduran, Sudan (2012). Michał Kobusiewicz "dancing” with dervishes. Photo: M. Jórdeczka.

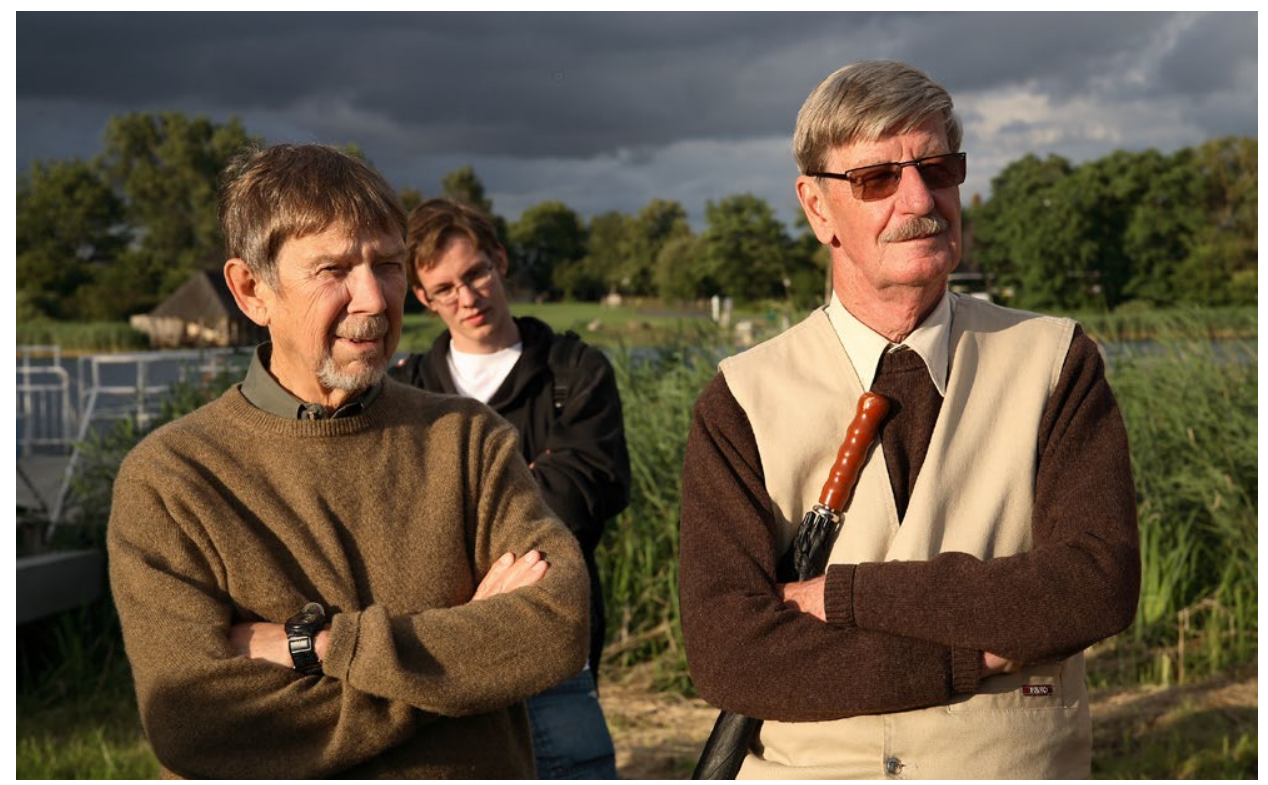

Fig. I6. Ostrów Lednicki, Poland (20I2). With John R. F. Bower on an excursion during the Dymaczewo Conference. Photo: M. Jórdeczka. 


\section{9}

Polskie badania stanowisk prahistorycznych poza Europą. In M. Brzostowicz (ed.), Archeologia polska i jej czasy, 6I-70. Poznań.

Gauges of Rhyolite in the Khartoum Neolithic. Example from Kadero (Sudan). In J. M. Burdukiewicz, K. Cyrek, P. Dyczek and K. Szymczak (eds), Understanding the Past. Papers offered to Stefan K. Koztowski, 195-198. Warsaw.

\section{0}

Gebel Ramlah. Final Neolithic Cemeteries from the Western Desert of Egypt. Poznań [with J. Kabaciński, R. Schild, J. D. Irish, M. C. Gatto and F. Wendorf].

Archeologa podróże po świecie. Podróże Poznaniaków. Kronika Miasta Poznania 20Io(3): 342-357.

Oaza kobiet (Women's Oasis). Archeologia żywa I: 26-33 [with E. Kuciewicz].

\section{1}

Preface. In M. Chłodnicki, M. Kobusiewicz and K. Kroeper (eds), Kadero: The Lech Krzyżaniak excavations in the Sudan, 7. Poznań. Studies in African Archaeology Io [with M. Chłodnicki and K. Kroeper].

Lithic implements. In M. Chłodnicki, M. Kobusiewicz and K. Kroeper (eds), Kadero: The Lech Krzyżaniak excavations in the Sudan, 267-298. Poznań, Poznań Archaeological Museum. Studies in African Archaeology IO.

Burial practices of the Final Neolithic Pastoralists at Gebel Ramlah, Western Desert of Egipt. In R. F. Friedman and P. N. Fiske (eds), Egypt at its Origins 3, 93-212. Leuven-Paris-Walpole MA [with J. Kabaciński, R. Schild, J. D. Irish and F. Wendorf].

Dakhleh Oasis Project: Petroglyph Unit. Rock art research, 2008. Polish Archaeology in the Mediterranean 20: 237-244 [with E. Kuciewicz].

\section{2}

Dakhleh Oasis Project. Petroglyph Unit: rock art research, 2009. Polish Archaeology in the Mediterranean 2I: $279-287$ [with E. Kuciewicz].

Nowe odkrycia prahistorycznej sztuki naskalnej w północno-wschodniej Afryce. Nauka 3: 155-166.

Loiyangalani: A Cultural isolate in the Middle Stone Age of Northern Tanzania. In J. Kabaciński, M. Chłodnicki and M. Kobusiewicz (eds), Prehistory of Northeastern Africa. New Ideas and Discoveries, 479-49I. Poznań, Studies in African Archaeology Ir [with J. R. F. Bower, and A. Z. P. Mabulla].

Badania nad sztuką naskalną w oazie Dachla (Pustynia Zachodnia, Egipt). Stanowisko o6/o9. Fontes Archaeologici Posnanienses 48: 237-24I [with P. Polkowski].

Bir Nurayet - The fertility cult in prehistoric art of the Sudan. In E. Anati (ed.), The Intellectual and Spiritual Expressions of Non-Literate Peoples, 5I-58. Capo di Ponte [with P. Bobrowski, M. Chłodnicki, M. Jórdeczka and K. Pluskota].

\section{3}

Rock art Research in the Dakhleh Oasis, Western Desert (Egypt). Petroglyph Unit, Dakhleh Oasis Project. Sahara 24: IOI-II8 [with P. Polkowski, E. Kuciewicz and E. Jaroni].

$\mathrm{Na}$ styku archeologii z etnologią. In R. Vorbrich and A. Szymoszyn (eds), Ethnos et potentia. Interdyscyplinarność w polskiej etnologii, 99-I08. Poznań [with P. Bobrowski and M. Jórdeczka].

What forced the prehistoric cattle-keepers to emigrate from the Red Sea Mountains? Studia Quaternaria 30(2): I35-I42 [with P. Bobrowski, M. Jórdeczka, M. Chłodnicki and J. Kusiak]. 
$36 \mid$ Przemystaw Bobrowski

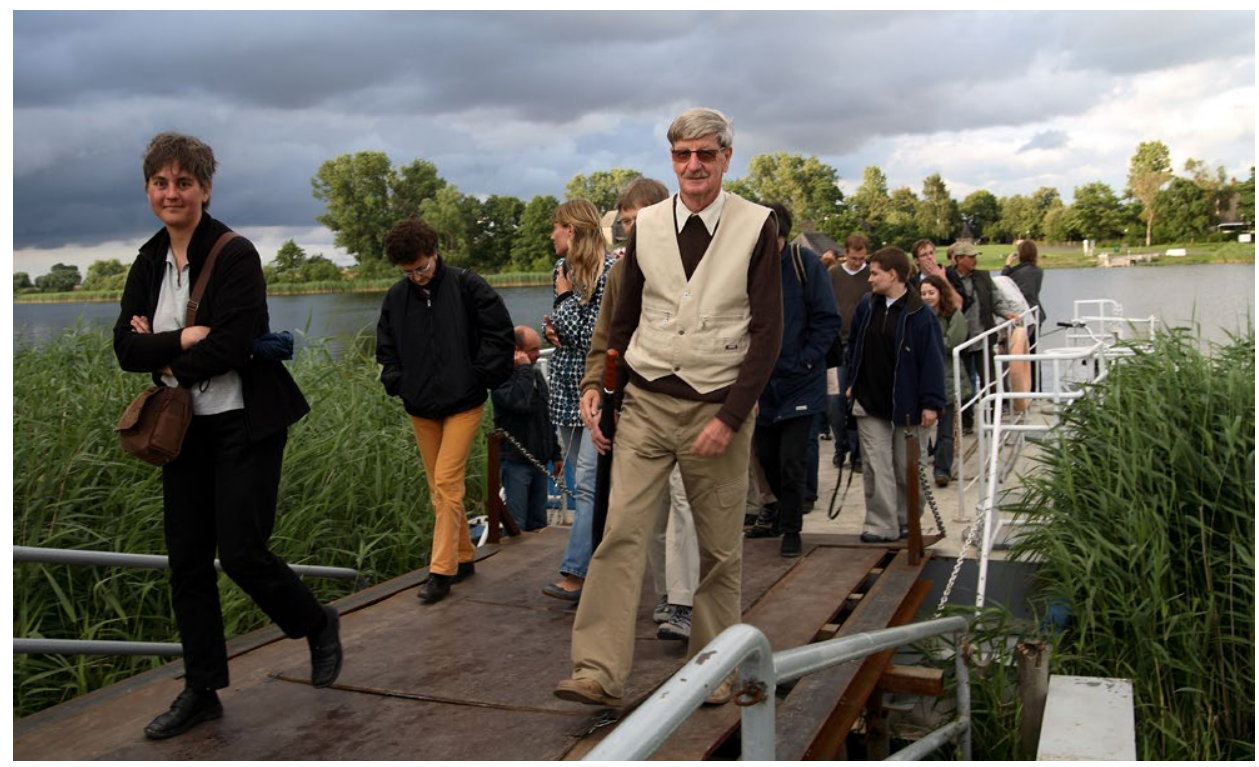

Fig. 17. Excursion to Ostrów Lednicki, Poland (2012). In the foreground: Friederike Jesse, Elena Garcea and Michał Kobusiewicz. Photo: M. Jórdeczka.

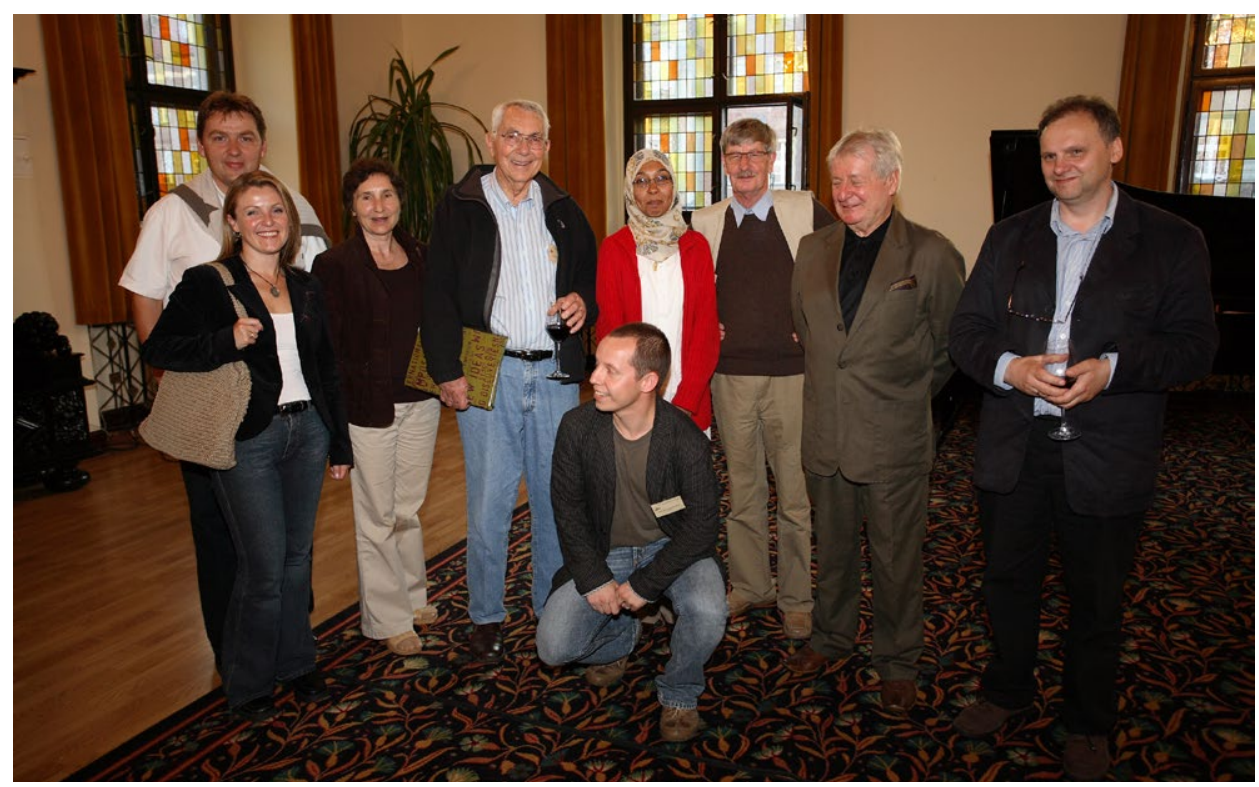

Fig. 18. Poznan, Poland (20I2). Members of the Combined Prehistoric Expedition.

From the left, standing: Przemysław Bobrowski, Agnieszka Czekaj-Zastawny, Halina Królik, Fred Wendorf, Hebatallah A. A. Ibrahim, Michał Kobusiewicz, Romuald Schild, Jacek Kobusiewicz. Kneeling: Maciej Jórdeczka. Photo: M. Jórdeczka (self-timer). 


\section{4}

Dakhleh Oasis Project, Petroglyph Unit: rock art research, 20II. Polish Archaeology in Mediterranean 23(I): 229-243 [with E. Kuciewicz and P. Polkowski].

\section{5}

The Production, Use and Importance of Flint Tools in the Archaic Period and the Old Kingdom of Egypt. Oxford. Dakhleh Oasis Project, Petroglyph Unit: Seasons 2012 and 2013. Polish Archaeology in Mediterranean 24(I): 275-296 [with E. Kuciewicz and P. Polkowski].

\section{6}

Chipped and Ground Stone Assemblages from Kom el-Hisn. In R. J. Wenke, R. W. Redding and A. J. Cagle (eds), Kom el-Hisn (ca.2500-I9oo BC). An Ancient Settlement in the Nile Delta, 337-341. Atlanta, Georgia.

\section{7}

Polskie badania sztuki naskalnej w Górach Czerwonomorskich (północno-wschodni Sudan). In A. Rozwadowski (ed.), Sztuka naskalna. Polskie doświadczenia badawcze, 26I-292. Warszawa-Toruń [with P. Bobrowski, M. Jórdeczka and M. Chłodnicki].

\section{8}

Sztuka naskalna w oazie Dachla w Pustyni Zachodniej w Egipcie. In B. Gediga, A. Grossman and W. Piotrowski (eds), Inspiracje i funkcje sztuki pradziejowej, In9-I27. Biskupin-Wrocław [with E. Kuciewicz, E. Jaroni and P. Polkowski].

Gebel Karaiweb and Bir Nurayet (Sudan). The Oldest Settlement in the Red Sea Mountains. In J. Kabaciński, M. Chłodnicki, M. Kobusiewicz and M. Winiarska-Kabacińska (eds), Desert and the Nile. Prehistory of the Nile Basin and the Sahara. Papers in honour of Fred Wendorf, 483-5I4. Poznań, Studies in African Archaeology Is [with P. Bobrowski, M. Jórdeczka and M. Chłodnicki].

Can the study of flint assemblages say something about the political relations in the early history of Egypt? In P. Valde-Nowak, K. Sobczyk, M. Nowak and J. Źrałka (eds), Multas per gentes et multa per saecula. Amici magistro et collegaue suo Joanni Christopho Koztowski dedicant, 555-559. Kraków.

Rola neolitycznych pasterzy sawanny w kształtowaniu się Starożytnego Egiptu. In A. Posern-Zieliński, J. Sawicka, J. Kabaciński, M. Kara and K. Zamelska-Monczak (eds), Archeologia jako humanistyczna interpretacja przesztości. Studia dedykowane Profesorowi Henrykowi Mamzerowi, 207-218. Poznań.

\section{9}

Khashm el-Girba, Sudan. In M. Chłodnicki and P. L. Polkowski (eds), Gdy Sahara byta zielona. Polskie badania archeologiczne nad prahistoria Afryki Pótnocnej (When Sahara was Green. Polish archaeological research on the prehistory of North Africa), 67-68. Poznań, Poznań Archaeological Museum [with M. Chłodnicki].

Moje wspomnienia $z$ archeologia $w$ tle. Poznań.

Review of M. Osypińska, Krowie królestwa. Zwierzęta w historii Doliny Środkowego Nilu. Studium archeozoologiczne. Przeglad Archeologiczny 67: 333-335. 


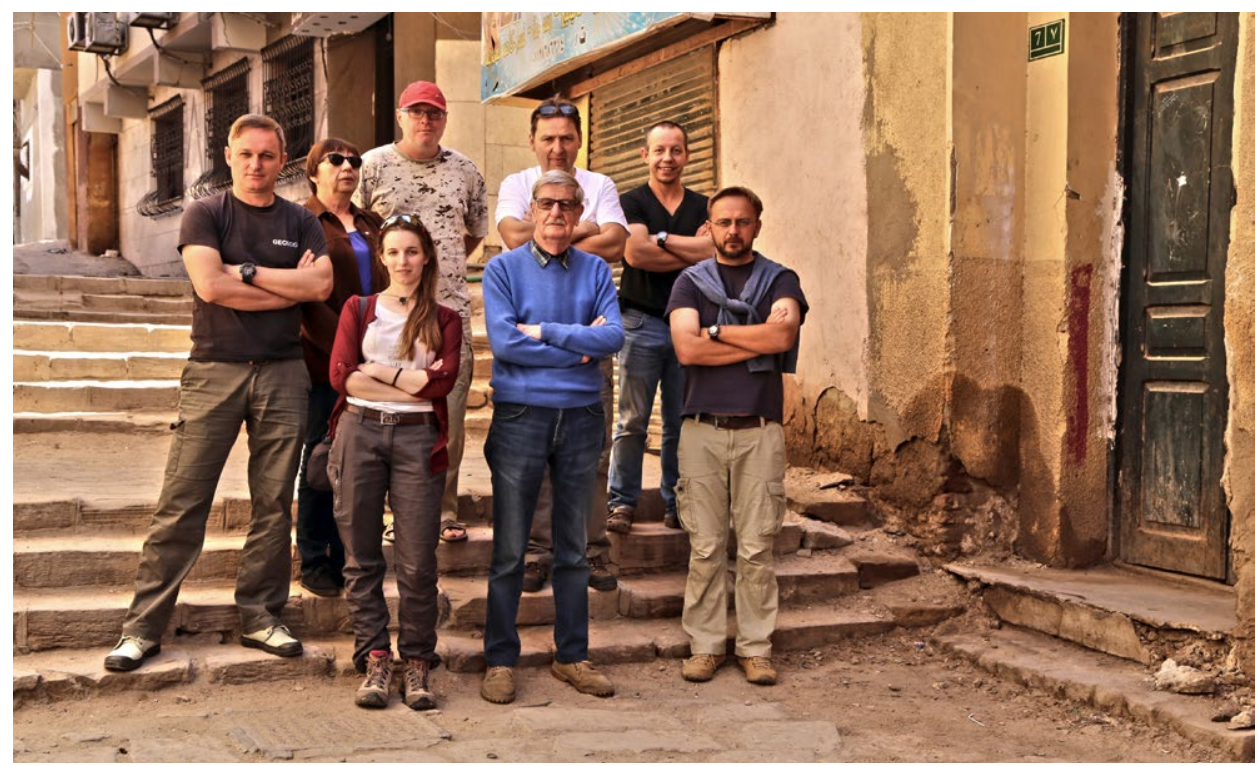

Fig. 19. Aswan, Egypt (2017). On the road to Bargat el-Shab in the Western Desert. From the left: Fabian Welc, Maria Lityńska-Zając, Patrycja Rutkowska, Paweł Wiktorowicz, Michał Kobusiewicz, Przemysław Bobrowski, Maciej Jórdeczka and Mirosław Masojć. Photo: M. Jórdeczka (self-timer). 